\title{
Meir Wieseltier: An Israeli Poet Reconstructing the Jewish Past
}

\section{David H. Hirsch Eli Pfefferkorn}

A meaningful discussion of modern Hebrew poetry ought to begin with the recognition that there has been a radical break in the Israeli cultural milieu. Americans exposed to the consciousness-shattering onslaughts of the mass media, the New Left, and the counter-culture may find the shift in the Israeli cultural scene timid, but from a more normative point of view the revolution in Israeli culture has been considerable. The full impact of the revolution has not been perceived outside of Israel (or even fully felt in Israel, for that matter) because the tradition oriented establishment has retained the ability to prop up the "old image" by means of its control of the universities, the newspapers, and the state operated radio, all of which are more conservative than their counterparts in the United States. The "establishment," it may be added, also controls the distribution of funds to be used for the support and advancement of "culture."

Nevertheless, one of the symptoms of the cultural revolution is keenly felt by the artistic community in Israel. The creative community in Israel has begun to suffer, indeed, has been suffering for some time, now, from that common western ailment: the alienation of the poet. Though divided on most other issues, both national and international, the Israeli literati seem to agree at least on one thing: that the last two decades have been characterized by a growing rift between the Hebrew poet and his audience. It is a well known datum of Israeli history, as well as of Zionist folklore, that the poetry of Nathan Alterman and Abraham Shlonsky, among others, used to be read, recited, and dramatized in the youth camps, around bon-fires. But while pre-state poetry used to be passionately debated in the dimly lit dining rooms of the kibbutzim, the poetry of the post-Palmach generation by and large has met with little public acclaim and even less popular acceptance. Apart from its impact on small circles of ardent enthusiasts, whose genuine devotion to lyric expression is not to be dampened, modern Hebrew poetry lies languishing in sublime seclusion. When Robert Alter wrote in 1965, that "Israel is probably one of the few remaining countries where verse, far from being a dying technique, has managed to stay at the vital centre of literary culture," he was describing a situation that had already ceased to exist.

By 1965, there had been a change both in the Israeli population and in the poets. The population was no longer a small cohesive group of idealists who had come to build a new state: it had grown rather to include the victims of the Holocaust, some of whom came for idealistic reasons and some of whom came because there was no place else to go. The generation of Alterman and 
Shlonsky addressed an educated readership with whom it shared common values and ideals. In general, both poet and reader tended to be future oriented, seeking redemption in the state that would one day be created to put an end to Jewish wandering and Jewish suffering. Hence, there was an immediate understanding of, and response to, what the poet wrote. In addition, both poet and reader were brought up on the Bible, Talmudic learning, and Jewish myth, all of which provided a shared intellectual and emotional frame of reference. This shared body of erudition and emotional sets, compounded with the still bloody wound of the Holocaust, established the closest possible ties between the poet and his readers. Their relationship was not unlike that of the minstrel and his listeners who responded to the song with emotional immediacy. However, this intimate poet-reader relationship has vanished in the new reality of the State of Israel.

The poet of the post-Palmach generation has not been blind and deaf to Jewish history and Jewish suffering, any more than his predecessors were, but he has had only a remote experience of the two most traumatic events in recent Jewish history: the death of European Jewry and the rebirth of the State. No longer do the young poets take for granted the unqualified identification with the Jewish fate explicitly expressed in the verse of the former generation. Their poetry, on the whole, is self-probing, their view of history ironic, and their Weltanschauung bleak. Daliah Rabicovitsch, a perceptive and articulate poet of the new generation, expresses the prevailing mood by saying that "what characterizes the young poets in this country is a sense of acute distress, much more acute than that felt by poets in other countries. This distress has its roots in things before the war and the Holocaust. It is the kind of distress that makes one want to turn back on the Jewish fate." Whereas the previous generation looked to the past in order to project a happier and more rewarding future, the current generation sees the happier future as its own non-utopian present. The modern Israeli poet, then, is concerned with the living agony of the Jew as modern Western man caught in a world of escalating technology and destructiveness and declining faith and hope.

There is one further element of change that is difficult to calculate. The earlier poetry was essentially an offshoot of Russian culture, with its tradition (still current, apparently) of "popular" narrative folk poetry. The recent poets tend to identify more with Western poetic tradition in general, and AngloAmerican imagist tradition in particular.

Our purpose in the present essay is to examine these new qualities in modern Hebrew poetry in the work of one poet of exceptional sensitivity and talent, Meir Wieseltier. He is, perhaps, too unique in his talents to be called typical, but the contours of his career are shared by many of his contemporaries. Born in Moscow in 1941, he was taken in July of the same year to Novosibirsk. After the customary postwar peregrinations of a DP through Poland, Germany, and France, he arrived in Israel with his family in 1949. His education has been Israeli, but he has lived extensively in London.

From the inception of his publishing career, Wieseltier has been an embattled 
poet. This conflict comes to the surface in the poem "Beware, the Secret's Out." In this poem, Wieseltier castigates the Israeli reviewers for not having come to grips with the aesthetics of his verse. His grievances are well founded. Both collections of Wieseltier's poetry, Chapter A and Chapter B (1967), and Hundred Poems (1969), were received unsympathetically by the critics, who have accused Wieseltier of linguistic mannerism, fanciful experimentation, and a generally blurred world view. What Wieseltier's critics failed to comprehend is that his alleged poetic adventurism reflects a sincere and uncompromising search for a new poetic idiom that would be appropriate to the sensibility of the modern Israeli. Partly, Wieseltier has puzzled his critics because his search for new modes of expression reflects an awareness of Jewish history that is, paradoxically enough, distant and intimate at the same time. In the poem "Saul Is Crowned the Second Time," Wieseltier returns to the Biblical past and also to a subject that has become pervasive in modern Hebrew poetry, having inspired, among others, poets of such different backgrounds and sensibilities as Saul Tchernichovsky, Nathan Zach, and Amir Gilboah. It is not difficult to see why Saul should appeal to poets. He was a complex personality, a man whose life and potential greatness were inexplicably, and even perversely, cut down by tragic and Job-like misfortunes, as if his inherent limitations outran his potential greatness before it could reach full flower. The Talmud has commented on this tragic fate that befell the king. In Yoma 22b, the Mishnah says, "Saul sinned once and it brought calamity upon him, David sinned twice and it did not bring evil upon him."

Working with subject matter that has become part of Jewish consciousness, Wieseltier departs from the conventional nineteenth-century attitudes, and in so doing perhaps comes closer to the Biblical king himself. Tchernichovsky, for example, taking as his text the Biblical verse, "So Saul died, and his sons and his armor bearer, and all his men that same day together," writes a romantic ballad about Saul's last battle:

One by one the heroes fell, at the sound

Of the horn, the great ones on the mountains of Gilboa

Tchernichovsky's narrator strikes the epic pose at once. Saul's heroism and the heroism of those who fought at his side is not problematic:

Fall upon your sword, and fall not by [the enemy's] hand.

The reader is invited to sympathize with acts of heroic men. Their exploits are seen from outside, as it were, and what Tchernichovsky does, essentially, is to sentimentalize the Biblical account and set it into heroic couplets.

Wieseltier veers away from this kind of sentimentalized narrative of the deeds of mighty men. His interest lies not in the acts of heroism per se but in the psychological complexity that is suggested by the problematic Biblical narrative. He writes about this hero, not in heroic couplets but in a series of images that 
seem to be a conflation of the events narrated in the first Book of Samuel. The poem is compressive rather than expansive. No governing text is given, but the opening image takes off from I Samuel 10:1, "Then Samuel took a vial of oil and poured it upon his head, and kissed him, and said, Has not the Lord anointed you to be prince over his people Israel?”

The mock-epic diminution is built into the image with which Wieseltier opens his poem:

Among your curls the new oil flows.

Don't you feel

The hidden difference, Saul?

The image of flowing oil shifts the focus of interest from the historical events to Saul's psychological condition. The scene of the anointment becomes a means of entry into the king's consciousness, as if the reader is permitted to seep with the oil into the king's skull. In the Biblical passage, Samuel asks, "Has not the Lord anointed you to be prince over his people Israel?" But in Wieseltier's poem, the speaker addresses an ironic question to Saul: "Do you feel/The hidden difference, Saul?" Both questions imply an answer: the Biblical question that the anointment carries divine sanction, the Wieseltier question, that the anointment is an empty ritual.

In stark contrast to Tchernichovsky's poem on Saul, emptiness pervades the Wieseltier poem. In the Tchernichovsky poem, Saul dies the noblest of a company of heroes. But in Wieseltier's poem, Saul is strikingly isolated. Wieseltier's Saul begins to assume the puzzling complexities of the Biblical figure: "Can you tell oil from oil. The look on the faces in the crowd/ Is not so springy now." The narrator's distance conveys the sense of Saul's precipitous decline from divine (and human) favor. Another ambivalent image conveys the element of fatedness in Saul's decline: "The new/ Sword, which in the future will fulfill its mission/ Given to you, as a present/ From legions expressing in this/ Their renewed loyalty ..." For Tchernichovsky, reproducing the Biblical account of Saul's suicide, the sword becomes a symbol of Saul's heroism. But for Wieseltier, it is a symbol of the mysterious and implacable hostility of God and man.

The reason for the hostility is never clear. Time has estranged the people from the king. But for the speaker, time has had the opposite effect. It has touched off a flow of warm feelings towards the slighted king. And in taking on the garb of a seer, the speaker of the poem predicts the tragic end of his king in a tone of touching lyricism. The seer sees into the future that has already been and predicts that the sword presented to the king is bound to turn against him.

Many of the elements present in the Saul poem are present, also, in a poem that deals with another layer of Jewish history. "Come See My Rebels" is a requiem for the defenders of Jerusalem during the Great Rebellion of the year 69 C.E. Although the style of the poem is basically lyrical, this lyricism is undercut by a subtly ironic tone. The poet describes the weary and resigned rebels 
as men who "knew that only on flaming beds/ at last/ would they come to rest," but despite this heroism, their stature is diminished. Stanza after stanza, Wieseltier strips down the layers of myth and legend that have accumulated around these fearsome events of the rebellion. Instead of portraying muscle-bound heroes who deftly swing swords and spears at the Roman enemy, Wieseltier's rebels are "thin and consumptive and splay-footed." Wieseltier's strategy in reducing the heroic stature of Yochanan of Gush-Halav and Shimon from the desert, is by no means a simple debunking of the rebels nor is it a demonstration of irreverence for the past. What this strategy indicates, it seems to us, is a re-orientation of the Jewish historical consciousness. The poet conceives of a historical event of fateful dimensions from the perspective of a modern Israeli whose concern is the existential human being rather than the projection of the historical hero.

But what seems, here, most characteristic of, and revealing about, the "Jewish consciousness" and "Jewish identity" as experienced by a young Israeli is its multi-layeredness. The ironies, ambiguities, and ambivalences of the speaker's voice seem to arise from the very nature of the Jewish "destiny" itself, an awesome, bloody history of a chosen people, a history which continues to develop and resonate in mystery, in chosenness, in a cycle of exile and return that is burdensome, troubling, totally demanding. How mixed these layers of history have become! Our speaker envisions "the rows of flats [that] now stand" in modern Jerusalem, still (in 1967, when the poem was published) an embattled city. And these rows of flats were built to welcome "olim hadashim," new immigrants gathered from exile. But where the flats now stand dreaming of these olim (immigrants and also those who ascend), those who will ascend out of exile up to the holy city, there once stood crosses that dreamt of other olim hadashim, those who would mount to crosses as victims. The strands of history projected by the beautiful word play become further entangled: the three crosses in Golgotha (where that other Jewish "rebel" was victimized) mix with the crosses that await these more recent Jewish rebels, including Simon Bar Giora, who also had messianic pretensions. The skeins of Jewish agony are bound in with the post-Jewish symbolism of human suffering-the mixing of blood, water, and wine.

Flavius represents another link in Jewish history, but a peculiar link, because Flavius was a participant in the events he records. Morever, he was an apostate who adopted not only the Roman style of recording history but also the Roman point of view. So there are, inevitably, some thing that "Flavius did not tell you."

And those things that Flavius did not tell are the things that must be recreated by the imagination of the new Jew returned from exile. What are these things? Essentially, they are the twin mysteries of chosenness and suffering, and the heroism that is the transformation of scarecrows ("And my rebels put on clothes/ that made them look like trees") into men who will fight desperately to preserve something (that something still a mystery-the commandments of a God who insists "Thou shalt have no other gods before me"), even in the face of insuperable odds and even in the knowledge that "only on flaming beds/ 
at last/ would they come to rest." This Flavius could not tell because having adopted the Roman point of view he himself could no longer understand these stiffnecked scarecrows, what it was that made them so intransigent, in the face of Roman Reason, as to refuse to buy tranquillity and comfort in exchange for worshipping pagan gods and Caesars. The supreme reality of their existence is stunningly projected in the concluding stanzas of the poem, which convey a sense of unmitigated terror, absorbing the horror of the death camps into the agony of Jewish history. Earlier, the speaker told us that "my rebels downed cheap wine and said;/ 'We will yet drink a toast in the cellars of Pilate.'" $\mathrm{He}$ also remarked that Flavius "knew there would be no toasts raised in the cellars of Pilate." And now, the speaker returns to this refrain, "my rebels drank wine and said ...." but this time there are no words, there is no bravado or labored self-delusion, only a soul-paralyzing silence. Yet out of this silence comes "the thump of hammers/ in the hands/ of the honest laborers": the hammers of time -of death. Like Jewish victims who listened to the thump of wheels of the transports wheeling them closer to death, the rebels are suddenly conscious of their abandonment, and they wait in silence for the death being prepared by "honest laborers" among their own people.

Whereas, generally, in his imaginative reconstruction of the historic past, Wieseltier faces the problem of bridging the aesthetic distance between the past and the present, in his re-experience of the Holocausts the difficulty that he confronts is how to create an aesthetic distance between the present and the past. In his description of the Rebels of the Second Temple, Wieseltier overcomes the aesthetic gap by an ironically subtle interplay between images. What he does is to contrast in a single image the modern apartment houses of the new Jerusalem with the crosses, both dreaming of new-comers. Similarly, in "Saul Is Crowned the Second Time," he captures the prevailing mood of the coronation through a device that can be best described as a verbal evocation. Saul's ascendancy to the crown irked many people who expressed their displeasure by deprecating the newly anointed king with, what has become also in modern Hebrew, a proverbial expression: "Is Saul also among the prophets?" (I Samuel 10:11-12). The proverb expresses surprise at Saul's election to the high post in the kingdom. Wieseltier re-echoes this widely known proverb by drawing on a closely related modern Hebrew phrase: "Mah Pittom," which is roughly equivalent to "How come?" thus associating it with "Is Saul also among the prophets?" Through this linguistic association that comes naturally to the Israeli Hebrew speaker, Wieseltier approximates the sensibilties of both epochs.

The attempt to link the past with the present through a recollection of related images or echo-structures is characteristic of Wieseltier's stratagem, as may be seen in both "Come See My Rebels" and "Saul Is Crowned the Second Time." For the modern Hebrew poet it seems emotionally much less problematic to give aesthetic shape to, and a rational account of, the events of the remote past than of the Holocaust. In his evocation of the past, the Hebrew poet's world is cushioned by the buffer of time and by the mass of literature that deals with the events of the First and Second Temples. But there exists no 
similar anaesthetizing distance and literature to soften the events of the Holocaust. In order to avoid excessive emotionalism in his poetry, the Hebrew poet often resorts to the employment of an objective correlative which allows him to give poetic utterance to what is otherwise unutterable, and describe what is beyond the scope of the human imagination. In choosing a "set of objects and situations" through which he projects the Holocaust experience, Wieseltier creates the necessary poetic distance between the artist and his subject-matter, and thus saves the poem from plunging into sentimentalism. The poem, "Three Baby-faced Germans" is a case in point. On the surface level the poem describes three young Germans sitting in a Parisian cafe on a rainy morning. The falling rain washes the street rubbish down the gutters and drenches the passers-by. But underneath the scenic description of the rainy Parisian morning there lurks the apocalyptic vision of the Holocaust.

The beautiful opening image already registers some of the shocking impact of the poem that is to be fully delivered in the closing lines of the second stanza. The dominant element in the image is softness and innocence, but the observer detects also a faint trace of decay in this nestling baby-faced trio, a decay underlined by the contrasting image, "so fresh upon the morning." To reinforce the paradoxical nature of the three baby-faced Germans, the speaker recalls the Biblical phrase used by Isaac in describing his simple-minded son, Esau. Like Esau, who came out of his mother's womb "red, all over like a hairy garment," the three baby-faced Germans ". . . smell of the field,/ their faces unshod."

The abrupt transition to the second stanza that presents a series of gutter images, "stale spit and yesterday's headlines," is poignantly contrasted with the images of innocence in the first stanza, and takes up the hints of disease and decay suggested in the opening image. The contrast between the image patterns of the first and second stanzas produces a shocking effect in the final four lines of the poem that usher in the apocalypse:

\section{Dripping down lashes of passers-by \\ Who glided like weeping columns \\ In windowpanes on squeaking hinges, \\ Facing them, the baby-faced Germans.}

What has taken place in these lines is a transmutation of the poetic material from the concrete to the symbolic. The rain has been transmuted to tears dripping from the lashes of the passers-by who in turn have assumed the shape of columns marching to the death chambers. The depressing silence of the gliding columns is brought into harsh relief with the squeaking windowpanes. The visual and the audible effect this image creates carries a wider and more complex reference. The image points to the breakdown of human compassion and moral responsibility in the residents sheltered in their houses, who, in the days of the Holocaust slammed the windows at the sight of the columns gliding to extermination. The alienated effect of the squeaking windowpane works on another level still. The speaker looks at the three baby-faced Germans watching the reflec- 
tions of the moving columns in the windowpanes. While for the Germans the Holocaust emerges as an image reflected in the annals of history, for the speaker the experience of the Holocaust is painfully alive, embodied in the very guts of his being.

The theme of "Three Baby-faced Germans" provides Wieseltier with the occasion to establish a kind of dialogue with another Holocaust poem: "Auschwitz, I Heard That You're in Style." In this poem, Wieseltier takes up the issue of expiation claimed by the German nation. Again drawing on a Biblical image, Wieseltier contends that the proclaimed purification of the Germans cannot obliterate the undeniable recorded facts of history. The pivotal image of whiteness on which the entire poetic constituents revolve is an indirect borrowing from Psalm LI, and possibly also from Isaiah 1-18.

In the psalm, as in Wieseltier's poem, whiteness and snow are associated with innocence and forgiveness. David pleads with God to "Purge me with hyssop, and I shall be clean, Wash me, and I shall be whiter than snow." Squarely facing his Creator, David takes responsibility for his past deeds and admits their irrevocability: "I acknowledge my transgression, And my sin is ever before me." But the Biblical echoes in Wieseltier's poem are ironic, because the Germans, unlike David, deliberately shun any confrontation with the past:

Auschwitz, I heard that you're in style.

Nice men talk about you with respect.

A little more, and you will be so swaddled

In paper leaves

That you will crunch like driven snow.

Everything will be whitest white, but for the printed letters

Sieg-heiling goose-stepping battalions.

The "paper leaves" once used to cover up their crimes in bureaucratic euphemisms are put to use again by "Nice men" to hide the memories of these criminal deeds. By contrasting white with black, Wieseltier brings into focus two opposing forces at work in the political realities of the twentieth century: the repeated attempts to whitewash the crimes perpetrated by the Germans, on the one hand, and the words of recorded history, on the other, that stand out as a grim reminder of "Sieg-heiling goose-stepping battalions."

The dialogue between "Auschwitz" and "Three Baby-faced Germans" is ironically rounded off in the closing lines in the two poems, which seem to be mirror reflections of each other. In these lines, victim and victimizer are depicted in a forward movement. But the victimizers march in a rhythmic beat of "Sieg-heiling goose-stepping," while the victims glide "like weeping columns."

Wieseltier's poetic vision of the Holocaust embodied in gutter and expiatory imagery takes a different vantage point in "Daddy and Mummy Went to the Movies." The poem describes the response of a little girl aged five or six to the Holocaust, which explodes into her consciousness in the form of an album 
of pictures of concentration camp inmates. Hers is a response of fascination to a bizarre world inhabited by strange and ugly creatures:

\author{
naked uncles \\ Running naked, so skinny \\ And also aunties with fannies bare \\ And men in pyjamas as in the theatre.
}

Unable to bear the depressing sight of the gloomy grownups, Ilana starts coloring them. She is especially drawn to

\author{
the bald skinny boy \\ She makes him such a huge red moustache \\ And at the end of the moustache perches a bird.
}

By the time Ilana has finished retouching the sombre reality of the concentration camp, the total pictorial effect is that of heavy bleakness dotted by a myriad of light and flashing colors. It is indeed a picture of Hell in color. Equipped with Freudian, Marxist, or other philosophical abstractions, the adult may find it easier to rationalize the events of the war. The child, however, whose perceptions have not been blunted by abstractions, has to soften what she perceives by dressing it up in color. The child in the poem is reminiscent in some ways of Blake's children. Ilana, innocent of intellectual structures, responds to the "gray" book. But her efforts to give color to this gray world do not result in any apocalyptic integration. Rather, the only way the imagination seems to have of coping with the gray Sheol-like reality of the concentration camp, a reality that will not be imagined away, is to convert the experience embodied in the pictures into a series of grotesque images. The already bizarre image of the "bald skinny boy" cannot be prettified. It can only be made even more grotesque with the addition of a "huge red moustache," at one tip of which "perches a bird." Nature has entered this gray world through the back door, as it were, and without coherence.

It is instructive to compare the Ilana poem to a short lyric by Wallace Stevens in which there appears a similar metaphorical structure:

This old, black dress,

I have been embroidering

French flowers on it.

This image has been interpreted by Michel Benamou as follows: "Imagination 'embroiders' on the black dress: death is old, permanent. The flowers are fragile, but they add color, in the way a French word does to a sentence. They are artificial, not natural flowers." The quintessential problem for twentieth-century man remains the same: In the absence of a transcendent absolute, what can the imagination do to ameliorate the fact of death without sugaring it over or covering 
it entirely? In both these poems, Wieseltier's and Stevens's, the imagination adds color to the sombre reality. But Stevens's imagination, far removed from immediate historical trauma, approaches "pure" poetry, or what he himself would have called the "supreme fiction." His rarefied image is almost entirely disengaged from the "impurity" of historical events: a black dress and French flowers. Wieseltier, on the other hand, is still oppressed by the burden of history, which weighs heavily on his consciousness, and from which he still cannot liberate his imagination. So instead of the immaculate "black dress," pure symbol of universal death, Wieseltier's death images remain rooted in the immediately painful flow of historic events that continues to assault Jewish consciousness. To the modern Jewish imagination the quintessential image of death remains the Zwangslager which continues to stand also as the physical fulfillment of the furthest reaches of the Romantic thanatoptic imagination.

Imagination, here, is called upon to make recent Jewish suffering bearable. In the poems on the rebels and Saul it is called upon to make the suffering of the remote Jewish past meaningful in the present. In both the historical poems, however, and those that deal with the recent Jewish past, the poet tries to cope with the problems besetting Jewish consciousness in compact images and in a language liberated from the more flowery and discursive rhetoric of his immediate predecessors among the Hebrew poets. To some extent, this imagisitic tendency recalls the poetics of Anglo-American modernism from Pound and the Imagists to the present, a tradition that Wieseltier knows well. But ample precedent for this "imagism" and compactness may be found in the Bible itself, another tradition that Wieseltier knows well. 